\title{
Challenges of Kenya's Vision 2030 and the Jubilee Manifesto: the Case of Old People Cash Transfer Pension Scheme in Nakuru County
}

\author{
Moses Mpuria Kindiki ${ }^{1} \&$ Charles Wambu ${ }^{1}$ \\ ${ }^{1}$ Department of Social Studies, Maasai Mara University, Narok, Kenya. \\ Correspondence: Moses Mpuria Kindiki, Department of Social Studies, Maasai Mara University, PO Box 2899-00100, \\ Nairobi, Kenya.
}

Received: March 9, 2015

Accepted: March 23, 2015

Available online: April 21, 2015

doi:10.11114/ijsss.v3i3.781

URL: http://dx.doi.org/10.11114/ijsss.v3i3.781

\begin{abstract}
Most Kenyans lack financial resources for retirement and rely on their families, yet the family is becoming a less reliable source of support in old age due to decreasing fertility and the increasing mobility of the young. In response, and as one of the strategies of realising Vision 2030, the Kenyan government has established an Old People Cash Transfer Pension Scheme (OPCTPS) as a form of social protection for the elderly. This study focused on the challenges of the OPCTPS in Kenya under the Jubilee Coalition government that came to power in 2013. The study used survey research design and the target population was sampled randomly from a list of registered beneficiaries to form 340 respondents and $10 \mathrm{key}$ informants. The data was collected using questionnaires for key informants and interview schedules for the respondents. The data was analysed using Statistical Package for Social Science computer program and was presented using descriptive statistics. The results of the study showed that the challenges which hindered implementation of the OPCTPS, in order of importance, include low coverage, low allocation of funds, credibility in management, delays in payments, high administrative costs, poor awareness and lack of relevant documents. The study findings may be used by policy makers to plan for better coverage of the OPCTPS. Also the results may be used by stakeholders to strategies on how to empower the aged and ageing people and in allocation of domestic resources. Above all, the Jubilee Coalition government in power should spearhead the passing of at least one Act of Parliament to consolidate the existing legal framework and policy on the OPCTPS.
\end{abstract}

Keywords: Old age, cash transfer, pension, beneficiary, stakeholder

\section{Introduction}

Worldwide older persons are regarded as a vulnerable group, and hence it is generally agreed that they are in dare need of government attention (Kiptim, 2007). This is because poverty affects this group than any other in the contemporary world, especially in developing countries. Older persons belong to the part of society that solely depends on the state and the family, and are always among the first to take the hit of any imperfect social protection system (Simon, 2011).

As of 2008, 62\% (313 million) of the world's people 65 years old and above lived in developing countries (Nyakundi, 2009). By 2040, developing countries are likely to be home to more than 1 billion people age 65 years and above, forming $76 \%$ of the projected older persons of the world total (Stiglitz, 2010). This striking statistic means that in several decades there will be many more old people. All these people will need financial support, and if the social security system cannot handle the loading now, the chance is slight that the necessary reforms will catch up fast enough. Therefore, governments need to plan for the unemployed and encourage them to participate in ensuring their own old age financial provisions are in place.

There is a link between poverty and social protection. Given the adverse effects of poverty, its eradication and alleviation are a matter that needs serious attention. Social security remains one of the most important means of both alleviating and eradicating poverty. By giving income through social security, households not only improve their consumption, but also can invest in the health and education of their children thus cutting the poverty circle (Amana, 2006).

In Kenya the changing demographic trends are on the increase as the number of the elderly increase compared to young people due to the scourge of Human Immunodeficiency Virus/ Acquired Immune Deficiency Syndrome (HIV/AIDS) which is killing majority of the reproductive youth (Njuguna, 2012). This is forecasted to increase the burden on the 
elderly to take care of the vulnerable and orphaned children left behind. Further, national poverty statistics clearly show that poverty is severe in households with a head who is above 60 years (Olivier, 2011). These trends may have some implications on policies that deal with provision of social security, health care and pension.

Moreover, over the past three decades, the living conditions of older persons in Kenya have deteriorated. This is as a result of the erosions of their economic power and changes in the family structure, particularly as far as the care of older members of the immediate family is concerned (Ahmad, 2009). This situation is worsened by the fact that the Kenyan economy almost only generates informal jobs, which are not subject to labour laws and do not foresee any form of social security for the aging population. Social security in Kenya is therefore the preserve of those in the formal sector as the design of such schemes specifically excludes those who are not in employment. As at 2012, about $13.5 \%$ of those in employment contribute to social security. This means that, with unemployment at $12 \%$ and a very large informal sector, majority of Kenyans will never have income in old age (Nyakundi, 2009). This means that the elderly do not have any income security yet they are being left to care for orphans owing to the ravages of HIV/AIDS pandemic.

Various efforts by various successive governments in Kenya have tried to address the needs of the older members in society without success. In Kenya, social protection has been implemented for several years through both non-contributory and contributory pension schemes. The Old People Cash Transfer Pension Scheme (OPCTPS) constitutes the major programme of the Ministry of Gender and Social Services. Its eligibility criteria is the retirement age of 60 years for men and women who do not have access to formal income security- and are therefore vulnerable to poverty. They are required to be registered with the scheme in the ministry to receive 2,000 Kenyan Shillings (KES) (United States Dollars (USD) 25) per month. The programme has only been piloted in selected districts such as Nakuru, Siaya, Muranga, Kisii, Lamu, Tana River and Nyeri. Approximately $6 \%$ of the older population now stands to benefit from the scheme (Odundo, 2008).

This signals, however, that there is still much to do to ensure income security in old age in Kenya. In this regard, the Jubilee Coalition government that came to power in 2013 allocated, in its first Budget (2013/2014 Financial Year) an additional KES 470 million (USD 5.4 million) to the OPCTPS, bringing the allocation to KES 1 billion (USD 11.4 million). Older people registered in the programme now receive KES 2,000 (USD 25) a month as opposed to the previous KES 1,500 (Nyakundi, 2009).

This move by the Jubilee Coalition government is anchored in its manifesto. The manifesto is built on three pillars: unity, economy and openness. Under the unity pillar, there are nine sub-pillars: national cohesion, security, trade and foreign affairs, sports and culture, healthcare, education, youth empowerment, women's empowerment and social protection. The main idea under social protection is helping the vulnerable. The Jubilee Coalition has identified the main challenge as unequal access to resources which fuels discontent and conflict. The opportunity envisaged is to correct the reflection of this inequality in the area of social protection by getting committed to fulfill the Vision 2030 ambition to make Kenya a middle-income country within a generation. The Coalition believes that a country with a thriving economy and a network of policies is able to provide a strong social safety net for the vulnerable. In this regard, the Coalition has articulated nine specific solutions in its manifesto: create a new legislative framework to place cash transfers for the needy on a solid foundation through a new system of social protection payments administered by County Governments; provide universal healthcare for all Kenyans by 2020, starting with the children, pregnant and breastfeeding women, people with disabilities, people with HIV/AIDS and the elderly; use the tax system to provide incentives to people to save for their old age; reform the National Social Security Fund (NSSF) to provide efficient and effective management; guarantee free water supplies to all those living in informal settlements pending slum upgrading; boost agricultural production through mechanisation, irrigation and assistance grants to smallholders; fully implement the constitution and guarantee all Kenyan communities equal access to natural resources; increase the reach of cash transfers to attain universal coverage for older persons and persons with disabilities and; include greater participation/inclusion for persons with disabilities in all sectors (Government of Kenya, 2013).

Two things come out from the above background. Firstly, although the expansion of the OPCTPS is slow, it demonstrates that Kenya is at the forefront in the region in providing social protection for its citizens (Odundo, 2008). The main problem however is that these programmes have been limited in scope and coverage (Amana, 2006). Reforms to improve the efficiency of the social security sector are therefore highly needed. Also, a vast understanding about the challenges on the implementation and operations of cash transfer pension scheme is highly needed. The dilemma of the efficiency of these reforms with regard to the pension industry is a big question to all stakeholders (Ahmad, 2009). Secondly, from the Jubilee Coalition's nine specific solutions addressed to the question of the vulnerable, four are central to this paper. These are the creation of a new system of social protection payments administered by County Governments, using the tax system to provide incentives to people to save for their old age, reforming the NSSF to provide efficient and effective management and increasing the reach of cash transfers to attain universal coverage for older persons and persons with disabilities. While the paper's focus has an implication on the four, its analysis will 
focus on only the first and last of these.

The purpose of this paper therefore is to evaluate the challenges in the implementation and operation of OPCTPS among the beneficiaries and stakeholders in Nakuru County under the Jubilee Coalition government.

\section{Literature Review}

\subsection{Background of the Pension Scheme in Kenya}

Basic social support can be implemented via public pension arrangements. Indeed social protection is increasingly being considered as contributing to the development process in the same way as health and education do. It is beyond the scope of this study to enter the debate over which type of social pension is most appropriate i.e. whether contributory or non-contributory. What is important here is that pensions have been shown to have implication for the broader society, as benefits are shared with household members- for example via providing food and school materials for grandchildren. Indeed older persons can often act as de facto heads of households caring for relatives infected with HIV/AIDS and looking after orphaned children (Haber, 2006). Around $30 \%$ of households in sub-Saharan Africa are headed by persons aged 55 years and over (World Bank, 2012). However over two thirds of the same households, including at least one child, are under the age of 15 years. According to Help Age International over $60 \%$ of orphaned children in Kenya live with their grandparents, receiving and sharing a pension. This cements inter-generation relationships and makes the elderly more integrated into communities rather than feeling like a burden to their families (Help Age International, 2006).

According to the International Labour Organisation, only one in five workers are covered by an adequate social security scheme (Odundo, 2008). According to the World Bank $85 \%$ of the world's population over 65 years of age have no retirement benefits at all. In sub-Sahara Africa less than $10 \%$ of the older population has a contributory pension (World Bank, 2012).

The ultimate goal of social protection is to ensure that all live in dignity and are given the opportunity to exploit their capabilities for social and economic development (Njuguna, 2012). In Kenya, this is reflected in the county's Vision 2030, which aims to provide a high quality of life for all its citizens by the year 2030. The Vision is built on three pillars- economic, social and political. The social pillar seeks to build a just and cohesive society with social equity in a clean and secure environment. This provides an impetus for the government to increase investment in social protection to the levels invested in comparable countries. One of the actions proposed to achieve this is the establishment of a consolidated social protection fund (cash transfer pension scheme). This fund is critical to the financing and sustainability of social protection of the vulnerable and the aged in the country. By participating in well-designed social security schemes, Kenyans who are able to contribute to their well-being and that of their dependants will also be supporting their country's economic and national development, as they will not need to become dependent on state support when confronted with a crisis. Social protection programmes will also enable Kenyans to access services.

Kenya's contributory pension scheme is fragmented and covers only $15 \%$ of the labour force. The enactment of the Retirement Authority Act 1997 did not in any significant way impact on the widening of the coverage of the system (Kiptim, 2007). The problem of low coverage is attributed to lack of an efficient policy aimed at widening of coverage and the current legal framework which was designed to target participation of formal workers. The implementation of the OPCTPS is therefore meant to run parallel to the NSSF.

\subsection{Actors in Social Protection}

The main function of social protection is to provide income security and access to health care and basic social services. There are three main actors who often play an important role in the development and management both of social security and of occupational or complementary schemes within the formal and informal sectors of the economy.

\subsubsection{Family and Local Solidarity Networks}

The role of the family in providing income security is essential, irrespective of a country's level of development. Income-sharing within the nuclear family provides income security for the young, old and for those (mainly women) who work at home. The family also tends to be the major source of care for young children and, though to a lesser extent, for adults with disabilities and elderly persons. The role of the extended family in providing income security for adult members who are elderly, sick or disabled varies considerably (Turner, 2010). In some countries of Africa and Asia it remains extremely important; elsewhere it has been eroded by recent social and demographic developments. Large families are often the best guaranteed source of income in old age, and for many people who are still not covered by any kind of social security system, this continues to be the case. Of course, even if the family is large and income is shared fairly within it, the family income may simply not suffice (World Bank, 2012). 


\subsubsection{Institutions of Civil Society}

Institutions of civil society which help to maintain income security through social protection are of many kinds: self-help groups providing assistance in kind or in the form of labour, savings societies, associations, cooperatives, mutual benefit societies, religious bodies and charities (Vij, 2011). Their role and their aims vary according to the national and local context. They may provide benefits in addition to those offered by public institutions, or they may be designed to afford a modicum of social protection for people who are not covered by any other system. The range of benefits which these institutions can offer is very wide. Some are devoted to food security, others to health insurance or pension provision; others provide compensation for death or disability (Stiglitz, 2010). They are generally financed from the beneficiaries' contributions, sometimes with subsidies from elsewhere. Because they are so close to the beneficiaries, they are generally able to offer benefits which correspond to the recipients' main priorities. Some of them may not have any legal status, as in the case of self-help groups providing assistance in kind or in the form of labour (Stewart \& Yermo, 2009). In general, however, the activities of these groups are governed by law and monitored by public authorities. Some social insurance systems had their roots in mutual benefit societies which became widely established and were ultimately converted into compulsory social security schemes (Slater \& Tsoka, 2007). In certain countries they have continued to play an important role by supplementing the benefits of the compulsory system, for example, in health care or in retirement provision. In other countries their role is limited to certain marginal groups.

\subsubsection{Government and Social Security Institutions}

In most countries the organisation and provision of social benefits is mainly the responsibility of public authorities. In historical terms, the development of national social protection systems often reflected the desire of legislators to harmonise and make compulsory various schemes which had developed in individual companies or sectors (Simon, 2011). It was a question of gradually ensuring that everyone had access to the same social rights. The structure of the social security scheme will often determine the arrangements for its administration. Thus, schemes which provide universal and means-tested benefits are more likely to be directly administered by the state (Rono, 2009). But there is a broad spectrum of institutional arrangements ranging from direct administration by a government department to reliance on private sector management. Where the social insurance tradition (or the contributory principle) is the strongest, as in France and Germany and throughout most of Africa, Asia and still much of Latin America and the Caribbean, schemes are generally administered by a public institution which is supervised by a board of directors or trustees and which, invariably, is legally autonomous (Seaman et al, 2008).

\subsection{Problems Associated with Social Protection}

\subsubsection{Low Coverage or Non-coverage}

A very large proportion of the population in most regions of the world still does not enjoy any social protection or is covered only very partially. This is the case for the vast majority of people in developing countries; and even in some of the richest industrialised countries there are large and growing gaps in social protection (International Social Security Association, 2008). Informal economy workers are not covered by social security for a variety of reasons. One of them is the extreme difficulty of collecting contributions from them and, as the case may be, from their employers. Another problem is that many of these workers are unable to contribute a relatively high percentage of their income to finance social security benefits and unwilling to do so when these benefits do not meet their priority needs. Their most immediate priorities tend to include health care, in particular where structural adjustment measures have reduced access to free services. They feel less need for pensions, for example, as for many of them old age appears very remote and the idea of retirement perhaps unreal (Hurrell et al, 2008). Unfamiliarity with social security schemes and distrust of the way they are managed adds to their reluctance to contribute.

The problem of low coverage is of course not new, especially in countries where large numbers of people work in subsistence agriculture (Macauslan, 2010). However, in recent years, prospects of resolving or at least mitigating it have taken a dramatic turn for the worse, as an increasing proportion of the urban labour force is working in the informal economy as a result of, inter alia, structural adjustment.

\subsection{Limited Coverage of the Formal Social Security Systems}

Related to the above problem is the fact that formal social security systems cover a small percentage of the population in most African countries. In pensions, coverage is low, both in terms of the total number of contributors over the economically active labor force, and the number of beneficiaries as compared to the population over 60 years of age (Davis and $\mathrm{Hu}, 2005$ ). That the coverage in relation to the overall population is low should not be surprising, since, as we have seen, the size of the formal labor force is small to begin with. Coverage in terms of the relevant target population is substantially higher, especially when formal sector employment is dominated by the public sector. 


\subsubsection{Credibility Problems}

There is a broad consensus among the beneficiaries and stakeholders that social protection is a powerful way to fight poverty and promote improved livelihood of the elderly. However, many formal social security systems especially in sub-Sahara Africa have experienced serious credibility problems due to many factors, such as low benefit levels, long lead times to process claims and poor services (Ellis et al, 2009). Credibility problems have affected all systemsprovident fund or defined contributions. Provident funds problems derive from the fact that the benefits they provide correspond to contributions plus returns, so that all risks are shifted to the beneficiaries (Dovi, 2010). Thus the mismanagement of reserves, administration costs, and poor administrative performance lead to meager pensions, in the best of cases. In many other cases, records cannot even be located. These problems help explain the move away from provident funds that has taken place in some countries (Devereux, 2011).

The credibility problems of the defined benefit schemes are similar to those of the provident funds regarding services provided. However, since benefits are defined, the risks of poor performance, mismanagement of funds et cetera are transferred to the government or to future generations. Unfortunately, however, beneficiaries have not been protected as well as one would expect from theory. The reason is that, often, governments, either by fiat or neglect, adjust benefits downward by failing, for instance, to index them to inflation (Devereux and White, 2011). In such cases, the consequences of poor performance are partially transferred to beneficiaries. Serious governance problems underlie the loss in credibility. At the root of the poor governance is a faulty institutional design. In many countries, the key problem has been the interference of the government in the management of the funds (Devereux, 2011). This interference has been encouraged by institutional designs that give government control of governing boards and the social security administrations.

\section{Methodology}

The study employed descriptive survey research design. Most of the beneficiaries were former freedom fighters who were settled in Nakuru County in different settlement schemes such as Nyakinyua, Elbergon, Piave and Ndeffo. Also they have been left with their grandchildren since their parents have died of the HIV/AIDS epidemic. About 340 respondents were randomly sampled from the register of the beneficiaries obtained from the office of the Ministry of Gender and Social Services in Nakuru County. About 10 key informants were purposively selected from the management team to form a total of 350 respondents. Data was collected using interview schedules for the beneficiaries due to high illiteracy levels among the beneficiaries, while questionnaires were used for key informants to verify information gathered from the beneficiaries. The data collected was analysed using the Statistical Package for Social Science.

\section{Results}

\subsection{Sources of Social Protection Cash}

From the respondents in the four sub-counties of Nakuru county most of the funds for social protection were derived from the government and an international non-governmental organisation known as Help Age International Kenya. The funds played a great role in provision of an income to the elderly as a form of social safety net.

\subsection{Characteristics of the Beneficiaries}

Table 1. Characteristics of the Beneficiaries

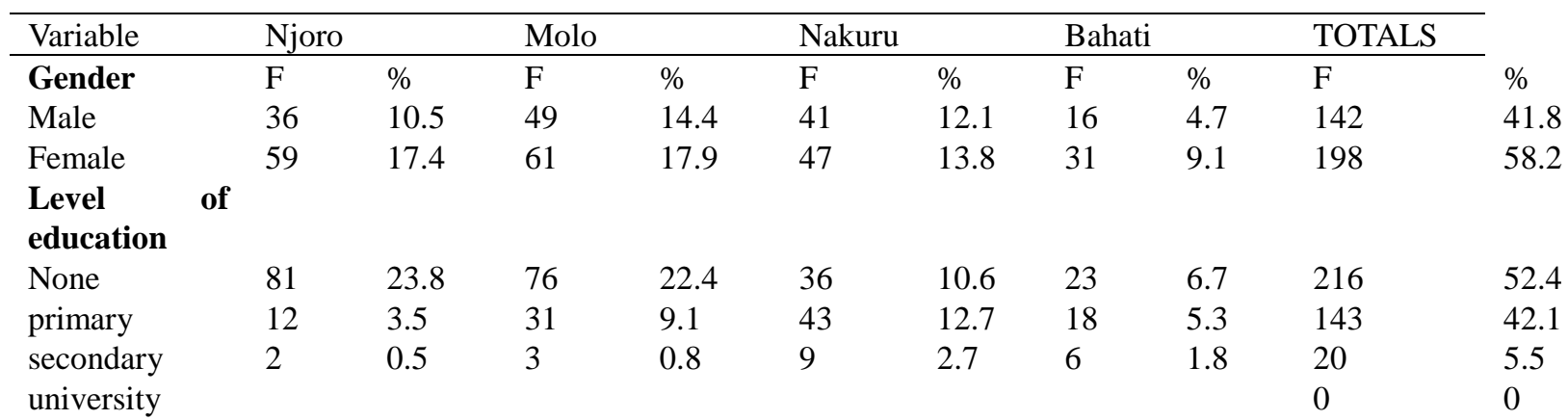

\section{Access to}

funds

Yes

No

Age cohort

61-70

95

27.9

110

32.4

88

25.9

47

13.8

340

100 


\begin{tabular}{|c|c|c|c|c|c|c|c|c|c|c|}
\hline $71-80$ & 39 & 11.5 & 32 & 9.4 & 42 & 12.4 & 18 & 5.3 & 131 & 38.5 \\
\hline $81-90$ & 16 & 4.7 & 11 & 3.2 & 17 & 5 & 13 & 3.8 & 57 & 16.8 \\
\hline $91 \&$ above & 14 & 4.1 & 10 & 2.9 & 16 & 4.7 & 5 & 1.5 & 45 & 13.2 \\
\hline \multicolumn{11}{|l|}{$\begin{array}{l}\text { No of } \\
\text { dependants }\end{array}$} \\
\hline $0-5$ & 15 & 4.4 & 32 & 9.4 & 38 & 11.2 & 17 & 5 & 102 & 30 \\
\hline $6-10$ & 71 & 23.8 & 67 & 19.7 & 41 & 12.1 & 24 & 7.1 & 203 & 59.7 \\
\hline 10-above & 9 & 2.7 & 11 & 3.2 & 9 & 2.6 & 6 & 1.8 & 35 & 10.3 \\
\hline \multicolumn{11}{|l|}{$\begin{array}{l}\text { Previous } \\
\text { occupation }\end{array}$} \\
\hline $\begin{array}{l}\text { Business } \\
\text { man/woman }\end{array}$ & 8 & 2.4 & 13 & 3.8 & 16 & 4.7 & 6 & 1.8 & 43 & 12.6 \\
\hline $\begin{array}{l}\text { Casual } \\
\text { labourer }\end{array}$ & 12 & 3.5 & 29 & 8.5 & 27 & 7.9 & 13 & 3.8 & 81 & 23.9 \\
\hline Self employed & 24 & 7.1 & 17 & 5 & 20 & 5.9 & 7 & 2.1 & 68 & 20 \\
\hline $\begin{array}{l}\text { Government } \\
\text { employee }\end{array}$ & 2 & 0.6 & 4 & 1.2 & 4 & 1.2 & 3 & 0.9 & 13 & 3.8 \\
\hline House wife & 49 & 14.4 & 47 & 13.8 & 21 & 6.2 & 18 & 5.3 & 135 & 39.7 \\
\hline
\end{tabular}

Source: Authors' Field Survey, 2014

Table 1 above shows the characteristics of the beneficiaries. Most respondents across the sub-counties were females (58.2\%); males were $41.8 \%$. This is an indication that there are more old women than men. This can be explained by the fact that in most communities men marry younger women than them, and hence the discrepancy in age. This is what accounts for more old women than men.

On average $31.5 \%$ of the beneficiaries were aged 61-70 years while $38.5 \%$ were aged $71-80$ years; $16.6 \%$ were aged $81-90$ years and $13.2 \%$ were aged 91 years and above. This is an indication that the scheme has engaged both aging and aged, and hence a great variation in household age data.

In the sub-counties, $30 \%$ of the respondents had 0-5 dependents, while $59.7 \%$ of the respondents had 6-10 dependants. $10.3 \%$ of the respondents had 10 or more dependants. Most of the beneficiaries are living with their grandchildren as their parents have died as a result of the scourge of HIV/AIDS. These have left the elderly with no other option but to be the care takers of their grandchildren. This has raised the burden of the elderly who do not have other sources of income. The number of dependants influenced the consumption and utilisation of the funds in meeting medical cover and physiological needs of the elderly. Also, the number of dependants influenced the source of farm labour and income in the family as some of the dependants are engaged in casual jobs to acquire extra income for the extended family.

Majority of the respondents (52.4\%) had never attended school, while $42.1 \%$ had primary education, while $5 \%$ had secondary education. This is an indication that most of the beneficiaries are illiterate, thus affecting the access to information and participation in the scheme. Literacy is also required to master the bureaucratic act of enrolling in such a scheme.

Due to low literacy levels the respondents had to work in less productive jobs and had to work in low paying activities, especially as casual labourers in rural areas. Majority of the respondents (23.9\%) were employed in white settlers farms as casual labourers, $39.7 \%$ were housewives and carried out domestic chores and have never been employed, while $12.6 \%$ were doing their business of trading farm commodities in make-shift markets where they could move from one trading center to another engaging in barter trade. 3.8\% were former government employees who were paid very little lump-sum amount of money as pension and utilised all the funds to pay school fees for their siblings. Most of the beneficiaries were engaged in informal employment after retiring from the Maumau movement that fought for Kenya's independence and after being isolated from their families. Currently most of them are engaged in small-scale farming and herding of animals. Most of the respondents claimed that they spent their youthful life as employees of European settlers and performed casual jobs which were not well paying.

From the study results $15 \%$ had 11 acres and above, while $66 \%$ had 5-10 acres; $8 \%$ had $1-4$ acres and $11 \%$ had 0.9 acres and below. 


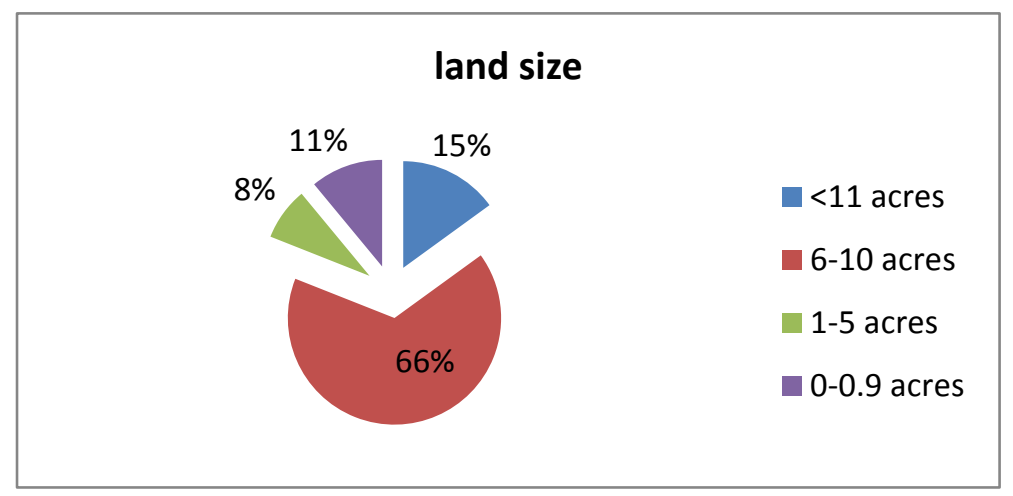

Figure 1. Land Size

Source: Authors' Field Survey, 2014

Most of the beneficiaries own small pieces of land that are uneconomical for farming. This was justified by the fact that the beneficiaries were unable to raise the number of shares required to join the land buying societies which were compensating the white settlers before one could have his/her share of piece of land. Most of the beneficiaries settled in Nyakinyua were settled by the government as a reward for the entertainment they used to give the late President Jomo Kenyatta at State House. They were rewarded with 5-10 acre pieces of land. Some of the beneficiaries, due to poverty, subdivided their land into plots and sold them to earn a living since some could not even support their medical cover. This has made their pieces of land become uneconomical for agricultural activities. Moreover some are aged and do not have the energy to cultivate the land. This is challenging to them since their siblings have migrated to town in search of better jobs, and hence food insecurity in the households of the elderly.

\subsection{Challenges of OPCTPS}

Table 2. Challenges of OPCTPS

\begin{tabular}{|c|c|c|c|c|c|}
\hline $\begin{array}{l}\text { Challenge of } \\
\text { cash transfer }\end{array}$ & $\begin{array}{l}\text { Major } \\
\text { Challenge } \\
(\%)\end{array}$ & $\begin{array}{l}\text { Minor } \\
\text { Challenge } \\
(\%)\end{array}$ & $\begin{array}{l}\text { Not a } \\
\text { Challenge } \\
(\%)\end{array}$ & $\begin{array}{l}\text { Don't } \\
\text { Know (\%) }\end{array}$ & Total $(\%)$ \\
\hline $\begin{array}{l}\text { Delayed } \\
\text { pavments (4) }\end{array}$ & 43 & 27 & 6 & 24 & 100 \\
\hline $\begin{array}{l}\text { Low amount } \\
\text { allocated (2) }\end{array}$ & 73 & 12 & 8 & 7 & 100 \\
\hline $\begin{array}{l}\text { High } \\
\text { administrative } \\
\text { (5) cost }\end{array}$ & 23 & 37 & 11 & 29 & 100 \\
\hline Credibility (3) & 53 & 25 & 15 & 7 & 100 \\
\hline $\begin{array}{l}\text { Low coverage } \\
\text { (1) }\end{array}$ & 81 & 9 & 3 & 7 & 100 \\
\hline
\end{tabular}

Source: Authors' Field Survey, 2014

Table 2 above shows the challenges of OPTCTPS. The common challenge identified by most of the beneficiaries was coverage of the scheme which accounted for $81 \%$. Low coverage of the funds has led to increase in poverty among the aged since they do not have alternative sources of income. All have not invested in any formal social security fund, and hence they face a challenge of meeting their physiological needs and medical cover. The scheme has not been able to factor in the aging group who deserve. The low amount given to beneficiaries was the second challenge cited, with $73 \%$ of the beneficiaries complaining that the funds were too low to cover their needs. Credibility was highlighted as the third most common challenge since it accounted for 53\%. This was as a result of corruption in management of the funds. Among the beneficiaries 14\% highlighted poor governance in the management of the funds. In most cases the funds are disbursed in post office savings accounts. The beneficiaries complained that when following up for the months not paid it consumes time and the officer's in-charge ask for bribes to facilitate payments.

Delayed payment was the fourth challenge which accounted for $43 \%$. This was as a result of procedural channeling of the funds to the beneficiaries and the inefficiency of financial institutions. They also highlighted inconsistence in the disbursement of the funds which accounted for $10 \%$. The last challenge highlighted was high administrative costs which accounted for $23 \%$ as the beneficiaries have to go far to collect the funds. Since they are illiterate, they have to be accompanied by their grandchildren to show them direction and to assist them during withdrawal of funds, and hence incurring more costs in travelling.

As far as awareness is concerned, $68 \%$ of the respondents claimed that they were not aware of the funds, while $32 \%$ 
were informed by relevant authorities. This affected the beneficiaries since they did not know the policy provision: whether both spouses to register as independent entities or if only one beneficiary should register; also, whether in case one beneficiary dies if the funds can be transferred to the next spouse. Most of the beneficiaries lamented about the criteria for identifying the beneficiaries as the local administration did not create awareness to the community members so they could register.

They also claimed that the documents required to register may not be available. This is because some of the elderly were unable to register for the new generation identity cards and some lack official documents because they have never been employed in their life.

\section{Summary and Conclusions}

Coverage of the OPCTPS is low, the KES 2, 000 given to beneficiaries is also too low to cover beneficiaries' needs and the scheme is not credible owing to corruption in the management of the funds. In addition, disbursement of funds is overly delayed and there are high administrative costs. Moreover, most potential beneficiaries are not aware of either the funds or the policies governing the scheme. They also claimed that often, they lack the documents required to register.

Despite these challenges there is growing interest across the county that safety nets (social cash transfers) have helped to raise the living standards of the elderly who are vulnerable. From the data the elderly are suffering in poverty due to lack of a comprehensive social security scheme. The government has the obligation of continuing to support the old to alleviate the poverty that is amongst themselves by enabling them meet their physiological needs and medical cover. It has come out clearly that the scourge of HIV/AIDS has added the aged with an extra role of taking care of grandchildren since their parents have died. Also, most of the old are facing the problem of lack of social security due to the economy generating informal employment, and hence the need to create awareness for individuals to register in retirement benefit authorities so as to have a saving culture for old age to reduce the burden on the government.

\section{Recommendations}

Policy makers should plan for the aged and aging persons in the informal jobs, who are not subject to a contributory pension and do not foresee any form of social security in their old age. This will help reduce poverty among the aged and the aging persons. Secondly, the aging need to establish their own individual contributory pension scheme to act as a social safety net during their old age. These will safeguard the family to be able to provide their needs and reduce the challenge of dependency. In addition, policies on old age social security should be reviewed to allow creation of awareness of the funds and solve the issue of transfer of the funds to the next spouse in case the other dies. Moreover, information sessions and seminars should be conducted in order to enhance awareness of the funds in the implementation process. This will help to reduce the levels of misconception among the targeted members. Finally, the Jubilee Coalition government should spearhead the passing of at least one Act of Parliament to consolidate the existing legal framework and policy on the OPCTPS. The process should be consultative to ensure that the interests of the stakeholders and beneficiaries are considered in making the regulations.

\section{References}

Ahmad, M. (2009). The impact of global challenges on retirement reforms in Africa. Paper presented at the IRF Conference.

Amana. (2006). Investment of pension fund assets in Kenya. Retrieved from www.rba.go.ke

Davis, R., \& Hu, W. (2005). Old age income support in the 21st century: An international perspective on pension systems and reforms. Washington D.C.: the World Bank.

Devereux, S. (2011). Investment and risk management under the new pension scheme. CBN Bullion, 30(2).

Devereux, S., \& White, F. (2011). Alternative methods for targeting social assistance to highly vulnerable groups. A report prepared by Kimetrica for Care International, Nairobi, Kenya.

Dovi, J. (2010). Are private transfers crowded out by public transfers? The case of Nepal. The Developing Economies, $X L I I(4), 510-528$.

Ellis, T., Devereux, S., \& White, F. (2009). The Ageing and development report: Poverty, independence and the world's older people. London: Earthscan Publications Ltd.

Government of Kenya (2013). Transforming Kenya, securing Kenya's prosperity 2013-2017: The shared manifesto of the coalition between the National Alliance, the United Republican Party, the National Rainbow Coalition and the Republican Congress Party. Nairobi: Government Printer.

Haber, D. (2006). Life review: Implementation, theory, research, and therapy, Aging \& Human Development, 63, 


\section{3-171. http://dx.doi.org/10.2190/DA9G-RHK5-N9JP-T6CC}

Help Age International (2006). Why social pensions are needed now. Retrieved from http: Ilwww.globalaging.org|pension|world12007\neededlpdf

Hurrell, J., Ward, C., \& Merttens, K. (2008). Selected resources on elder abuse: An annotated bibliography for researchers and educators. USA: University of Maryland.

International Social Security Association (2008). Application of performance contracting in social security administration in Kenya: The case of the National Social Security Fund. Geneva: International Social Security Association.

Kiptim, J. (2007). A reasonable and sustainable standard of living for every Kenyan worker after retirement. Retirement Benefits Authority. Retrieved from www.rba.go.ke

Macauslan (2010). Kenya OVC-CT programme: Operational and impact evaluation. Final Report. Oxford Policy Management.

Njuguna, A. (2012). Critical success factors for a micro-pension plan: An exploratory study. International Journal of Financial Research. Retrieved from http://sciedu.ca/journal/index.php/ijfr/article/view/185

Nyakundi, B. (2009). Pension coverage in Kenya: Legal and policy framework required to encourage coverage in Kenya. Retrieved from www.ssrn.com

Odundo, E. (2008). Supervision of pension: Kenyan experience. Paper presented at the Pension Supervision Workshop, Dakar, Senegal.

Olivier, M. (2011). Kenyan social security context: Overall goals and conceptual framework. Nairobi: International Institute for Social Law and Policy.

Rono, L. J. (2009). An evaluation of factors influencing pension managers' investment decisions in Kenya. International Business \& Economics Research Journal, 8(10), 25-57.

Seaman, J., Petty, C., \& Kambewa, P. (2008, June). The impact on household income and welfare of the pilot social cash transfer and agricultural input subsidy programmes in Mlomba TA, Machinga district, Malawi. Malawi Vulnerability Assessment Committee. Retrieved from http://www.wahenga.org/sites/default/files/EvDev_Mlomba_Survey_2008_Report.pdf

Simon, C. (2011). Disjunctures and contradictions: The role of measurement in poverty representation, policy, and development practice (Unpublished $\mathrm{PhD}$ dissertation). University of Colorado, Colorado.

Slater, R., \& Tsoka, M. (2007). Social protection in Malawi: A status report. Country Working Paper. Washington D.C.: World Bank.

Stewart, F., \& Yermo, J. (2009). Pensions in Africa. Organisation for Economic Cooperation and Development Working Papers on Insurance and Private Pensions. Paris: Organisation for Economic Cooperation and Development.

Stiglitz, J. (2010). Debates on the measurement of poverty: Summary and synthesis report. Oxford: Oxford University Press.

Turner, S. (2010). A social development policy framework for Botswana. Phase I: Situation analysis. Report commissioned by the Ministry of Local Government of the Republic of Botswana. Gaborone: Republic of Botswana.

Vij, N. (2011). Building capacities for empowerment: The missing link between social protection and social justice. Sussex: Institute of Development Studies and Centre for Social Protection.

World Bank (2012). Pensions in Sub-Saharan Africa. Washington D. C.: World Bank.

\section{(cc) EY}

This work is licensed under a Creative Commons Attribution 3.0 License. 